\title{
Brevibacterium samyangense sp. nov., an actinomycete isolated from a beach sediment
}

\author{
Soon Dong Lee
}

Correspondence

Soon Dong Lee

sdlee@cheju.ac.kr
Department of Science Education, Cheju National University, Jeju 690-756, Republic of Korea
The genus Brevibacterium, originally proposed by Breed (1953), is clearly differentiated from actinomycete genera with coryneform morphology on the basis of chemotaxonomic characteristics (Collins et al., 1983) and 16S rRNA gene sequence analysis (Heyrman et al., 2004; Wauters et al., 2004).

The genus contained, at the time of writing, 15 recognized species, mainly recovered from dairy products, clinical specimens, poultry and terrestrial environments, although a few, including Brevibacterium celere (Ivanova et al., 2004) and Brevibacterium stationis (Jones \& Keddie, 1986), were recovered from samples collected in marine environments. In the 16S rRNA gene sequence studies performed by Heyrman et al. (2004), B. stationis was shown to be related to members of the genus Corynebacterium. In the present study, a novel member of the genus Brevibacterium, recovered from beach sediment, was characterized taxonomically by use of a polyphasic approach. The resultant data supported that the organism should be classified as a novel species of the genus Brevibacterium.

During a study of marine actinomycetes, strain SST $-8^{\mathrm{T}}$ was isolated from beach sediment of the coast of Jeju Island,

The GenBank/EMBL/DDBJ accession number for the 16S rRNA gene sequence of strain SST-8 ${ }^{T}$ is DQ344485.
Republic of Korea, and its taxonomic status was investigated. A sediment sample was taken at a depth of $30 \mathrm{~cm}$ below the beach surface. For bacterial isolation, $1 \mathrm{~g}$ sediment was placed into a sterile plastic tube containing $9 \mathrm{ml}$ sterile distilled water and mixed in a tube rotator for $30 \mathrm{~min}$. After aliquots $(100 \mu \mathrm{l})$ of the sample were transferred into the isolation medium, the agar plates were incubated at $30^{\circ} \mathrm{C}$ for 14 days. The isolation medium (SCSW agar) consisted of $1 \%$ soluble starch, $0.03 \%$ casein, $0.2 \% \mathrm{KNO}_{3}, \quad 0.2 \% \mathrm{NaCl}, 0.002 \% \mathrm{CaCO}_{3}, 0.005 \%$ $\mathrm{MgSO}_{4} .7 \mathrm{H}_{2} \mathrm{O}, 0 \cdot 001 \% \mathrm{FeSO}_{4} .7 \mathrm{H}_{2} \mathrm{O}, 1 \cdot 8 \%$ agar, $60 \%$

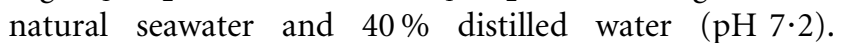
Colonies were subcultivated on ISP2 medium (Shirling \& Gottlieb, 1966) supplemented with $60 \%(\mathrm{v} / \mathrm{v})$ sterilized natural seawater (YE-SW agar). Pure cultures were maintained on YE-SW agar plates and in $20 \%(\mathrm{v} / \mathrm{v})$ glycerol solution supplemented with $60 \%(\mathrm{v} / \mathrm{v})$ sterilized natural seawater at -20 and $-80^{\circ} \mathrm{C}$.

Analysis of cellular fatty acids was performed according to the instructions of the Microbial Identification System (MIDI) (Sherlock Microbial Identification System; Hewlett Packard), with cells grown on trypticase soy agar for $48 \mathrm{~h}$. Other chemotaxonomic characters were analysed as described by Lee et al. (2000b) as follows: the isomer of diaminopimelic acid (Staneck \& Roberts, 1974), mycolic acids (Minnikin et al., 1980), polar lipids (Minnikin et al., 
1977) and lipoquinones (Kroppenstedt, 1985). The fatty acid profile of strain SST- $8^{\mathrm{T}}$ was characterized by the predominance of anteiso- $\mathrm{C}_{17: 0}(35 \cdot 3 \%)$, anteiso- $\mathrm{C}_{15: 0}$ $(29 \cdot 9 \%)$ and iso- $\mathrm{C}_{15: 0}(15 \cdot 5 \%)$, which is consistent with profiles for members of the genus Brevibacterium (Funke \& Carlotti, 1994). Other fatty acids present at levels above $1 \%$ were iso- $\mathrm{C}_{17: 0}(4 \cdot 2 \%), \mathrm{C}_{16: 0}(4 \cdot 2 \%), \mathrm{C}_{18: 0}(4 \cdot 0 \%)$, iso$\mathrm{C}_{16: 0}(2 \cdot 5 \%)$ and $\mathrm{C}_{18: 1}(1 \cdot 9 \%)$. Whole-cell hydrolysates contained meso-diaminopimelic acid; mycolic acids were not present and the predominant menaquinone was MK$8\left(\mathrm{H}_{2}\right)$. All of these features are consistent with the chemotaxonomic description of the genus Brevibacterium (Collins et al., 1983). The polar lipid profiles contained significant amounts of phosphatidylglycerol, but not diphosphatidylglycerol or phosphatidylinositol found in other members of the genus (Jones \& Keddie, 1986).

Purification of chromosomal DNA was carried out by using the Wizard genomic DNA purification kit (Promega) according to the manufacturer's instructions. The $16 \mathrm{~S}$ rRNA gene of strain SST $-8^{\mathrm{T}}$ was amplified by PCR as described by Lee et al. (2000a) and was subjected to direct sequence determination using an ABI PRISM BigDye Terminator cycle sequencing kit (Applied Biosystems) and an automatic DNA sequencer (model 3730xl; Applied Biosystems). The almost-complete $16 \mathrm{~S}$ rRNA gene sequence of strain SST $-8^{\mathrm{T}}$ was determined $(1426 \mathrm{nt})$, and the results of an initial BLAST search against GenBank sequence data indicated that the organism was related to the genus Brevibacterium of the family Brevibacteriaceae. Multiple alignment of the sequences was performed by using the CLUSTAL X program (Thompson et al., 1997) and then manually optimized following the secondary structure of the bacterial 16S rRNA gene. Phylogenetic analyses were performed using three tree-making algorithms, namely the neighbour-joining (Saitou \& Nei, 1987), maximumlikelihood (Felsenstein, 1981) and maximum-parsimony (Fitch, 1971) methods. A phylogenetic tree was reconstructed based on the neighbour-joining method from evolutionary distances calculated according to the method of Jukes \& Cantor (1969). Confidence in the tree topology was evaluated by bootstrap analysis (Felsenstein, 1985) of 1000 replicated datasets. The neighbour-joining tree (Fig. 1) showed that strain SST- $8^{\mathrm{T}}$ formed an intermediate branch between the Brevibacterium luteolum/Brevibacterium otitidis and Brevibacterium mcbrellneri/Brevibacterium paucivorans clusters with $73 \%$ bootstrap support. This relationship was supported by all tree-making methods used in this study. Sequence similarity calculations after a neighbour-joining analysis revealed that the closet relatives of strain SST- $8{ }^{\mathrm{T}}$ were the type strains of $B$. paucivorans $(96 \cdot 6 \%)$, B. luteolum (96.5\%), B. mcbrellneri $(96 \cdot 3 \%)$, Brevibacterium avium $(96 \cdot 0 \%)$ and $B$. otitidis $(95 \cdot 9 \%)$. Levels of $16 \mathrm{~S}$ rRNA gene sequence similarity between strain SST- ${ }^{\mathrm{T}}$ and the other recognized Brevibacterium species were in the range $95 \cdot 0-95 \cdot 5 \%$. The results of these $16 \mathrm{~S}$ rRNA gene sequence comparisons indicate that the isolate can be assigned to a separate genospecies without the need for further DNA-DNA

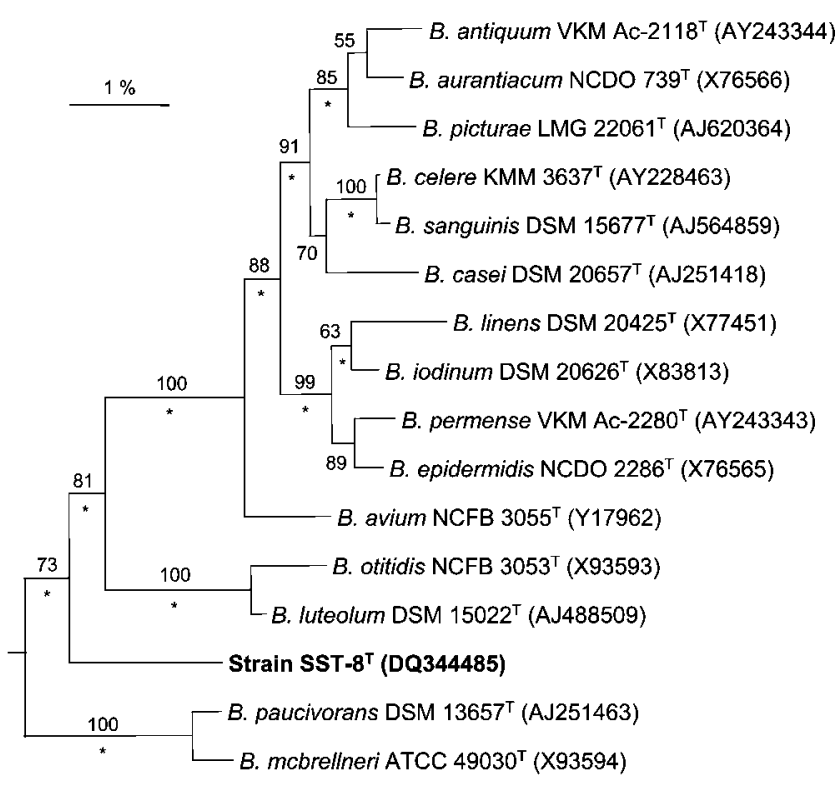

Fig. 1. A neighbour-joining tree based on 16S rRNA gene sequences showing the phylogenetic position of strain SST-8 ${ }^{\top}$ within the radiation of the genus Brevibacterium. Evolutionary distances for tree construction were calculated using the Jukes-Cantor coefficient. Micrococcus luteus ATCC $381^{\top}$ (M38242) was used as outgroup taxon (not shown). Asterisks indicate that the corresponding branches were also recovered in the maximum-likelihood and maximum-parsimony trees. Numbers at nodes indicate percentages of bootstrap support based on a neighbour-joining analysis of 1000 replicated datasets. Bar, 1 nucleotide substitution per 100 nucleotides.

hybridization experiments (Stackebrandt \& Goebel, 1994). The DNA G + C content determined for strain SST $-8^{\mathrm{T}}$ was $70 \cdot 7 \mathrm{~mol} \%$.

Colony pigmentation was observed visually and recorded after 5 days growth at $30^{\circ} \mathrm{C}$ on YM-SW agar. Cell morphology was determined on cultures grown for $6,12,16,24$ and $72 \mathrm{~h}$ on YE-SW agar at $30^{\circ} \mathrm{C}$. Cell suspensions were made in sterile distilled water, stained negatively with India ink and observed by using a light microscope (magnification $\times 1000$ ). Cell motility was observed under an Olympus light microscope equipped with phase-contrast optics (magnification $\times 400)$ and further confirmed by the presence of turbidity throughout the tube including semisolid medium. Temperature for growth was tested at 4, 10, 20, 30, 35, 42, 45 and $55^{\circ} \mathrm{C} . \mathrm{NaCl}$ tolerance was studied on ISP2 medium containing $\mathrm{NaCl}$ at final concentrations of $0-15 \%(\mathrm{w} / \mathrm{v})$. Catalase activity was determined with a $3 \%(\mathrm{v} / \mathrm{v})$ hydrogen peroxide solution. Oxidase activity was observed by oxidation of $N, N, N^{\prime}, N^{\prime}$-tetramethyl-p-phenylenediamine. The ability of the organism to utilize a variety of substrates as sole carbon source was tested using GP2 microplates of the Microlog system (Biolog; 95 substrates). Cells were grown for 3 days at $30^{\circ} \mathrm{C}$ on YE-SW agar and suspended in $2 \%(\mathrm{w} / \mathrm{v})$ sea salts solution (Sigma). An aliquot of the suspension 
$(150 \mu \mathrm{l})$ was transferred to each well, and the plates were incubated for $48 \mathrm{~h}$ at $30^{\circ} \mathrm{C}$. Reduction of tetrazolium dye was determined by reading the microtitre plates at $595 \mathrm{~nm}$ using the microplate reader. API CORYNE and API ZYM strips (bioMérieux) were used according to the manufacturer's instructions. Degradation of casein, DL-tyrosine and xanthine was examined using the method described by Gordon et al. (1974). The results of the morphological, cultural and physiological characterization are given in the species description below.

Phenotypic features that can be used to differentiate between the new isolate and its phylogenetic neighbours within the genus Brevibacterium are given in Table 1. The combination of phenotypic and genotypic data supports that strain SST$8^{\mathrm{T}}$ be classified as the type strain of a novel species of the genus Brevibacterium, Brevibacterium samyangense sp. nov.

\section{Description of Brevibacterium samyangense sp. nov.}

Brevibacterium samyangense (sam.yang' en.se. N.L. neut. adj. samyangense of Samyang Beach, Jeju, Republic of Korea, from where the type strain was isolated).

Cells are Gram-positive, catalase-positive, oxidase-negative, motile and non-spore-forming. On YE-SW agar, an apparent rod-coccus growth cycle is observed: after $6 \mathrm{~h}$ growth, cells are coccoid, occurring singly or in pairs, with the rare occurrence of short rods; after 12 and 16 h growth, most cells are irregular and slender rods, arranged in Vforms; after 24 and $72 \mathrm{~h}$ growth, cells are coccoid, occurring singly, in pairs or in chains. Colonies are opaque, convex, circular and bright yellow in colour with an entire edge. Temperature range for growth is $10-45^{\circ} \mathrm{C}$. No growth is observed at 4 or $55^{\circ} \mathrm{C}$. Growth occurs in the $\mathrm{pH}$ range $6 \cdot 1-10 \cdot 1$, with better growth at higher $\mathrm{pH}$. $\mathrm{NaCl}$ tolerance for growth is observed, with good growth at $0-5 \%$, moderate growth at $6-9 \%$ but only weak growth at 10 or $15 \% \mathrm{NaCl}$. Degradation of DL-tyrosine is observed but not of casein or xanthine. The following substrates are utilized as sole carbon and energy sources for growth in Biolog GP2 tests: $\beta$-cyclodextrin, dextrin, glycogen, inulin, mannan, Tweens 40 and $80, N$-acetyl-D-glucosamine, $N$-acetyl- $\beta$-Dmannosamine, amygdalin, L-arabinose, D-arabitol, arbutin, D-cellobiose, D-fructose, L-fucose, D-galactose, D-galacturonic acid, $\alpha$-D-glucose, myo-inositol, $\alpha$-D-lactose, lactulose, maltose, maltotriose, D-mannitol, D-mannose, D-melezitose, D-melibiose, methyl $\alpha$-D-galactoside, methyl $\beta$-Dgalactoside, 3-methyl D-glucoside, methyl $\alpha$-D-glucoside, methyl $\beta$-D-glucoside, methyl $\alpha$-D-mannoside, palatinose, D-psicose, D-raffinose, L-rhamnose, D-ribose, salicin, sedoheptulosan, D-sorbitol, stachyose, sucrose, D-tagatose, Dtrehalose, turanose, xylitol, D-xylose, acetic acid, $\alpha$-, $\beta$ - and $\gamma$-hydroxybutyric acids, $p$-hydroxyphenylacetic acid, $\alpha$ ketoglutaric acid, $\alpha$-ketovaleric acid, lactamide, D-lactic acid methyl ester, L-lactic acid, L-malic acid, methylpyruvate, monomethylsuccinate, propionic acid, succinamic acid, succinic acid, $\mathrm{N}$-acetyl-L-glutamic acid, Lalaninamide, D- and L-alanine, L-alanylglycine, L-asparagine, L-glutamic acid, glycyl L-glutamic acid, L-pyroglutamic acid, L-serine, putrescine, adenosine, 2'-deoxyadenosine, inosine, thymidine, uridine, adenosine $5^{\prime}$-monophosphate, thymidine $5^{\prime}$-monophosphate, uridine $5^{\prime}$-monophosphate, $\alpha$-D-glucose 1-phosphate, D-glucose 6-phosphate and DL- $\alpha$ glycerol phosphate. The following substrates in the Biolog GP2 system are not utilized: $\alpha$-cyclodextrin, gentiobiose, Dgluconic acid, D-malic acid, 2,3-butanediol, glycerol and Dfructose 6-phosphate. In the API CORYNE system, pyrazinamidase, pyrrolidonyl arylamidase, alkaline phosphatase, $\beta$-galactosidase and $\alpha$-glucosidase are positive. Nitrate reduction, $\beta$-glucuronidase, $N$-acetyl- $\beta$-glucosaminidase, $\beta$-glucosidase (aesculin hydrolysis), urease, gelatin

Table 1. Differential phenotypic characteristics of strain $\mathrm{SST}_{-} \mathrm{8}^{\top}$ and its phylogenetic relatives in the genus Brevibacterium

Taxa: 1, strain SST-8 ${ }^{\mathrm{T}}$; 2, Brevibacterium avium (data from Pascual \& Collins, 1999); 3, Brevibacterium luteolum (Wauters et al., 2003); 4, Brevibacterium mcbrellneri (McBride et al., 1993); 5, Brevibacterium otitidis (Pascual et al., 1996); 6, Brevibacterium paucivorans (Wauters et al., 2001). Characteristics are recorded as: +, positive; W, weakly positive; -, negative; ND, no data available; ?, conflicting results between data given in species description and table of differential characteristics.

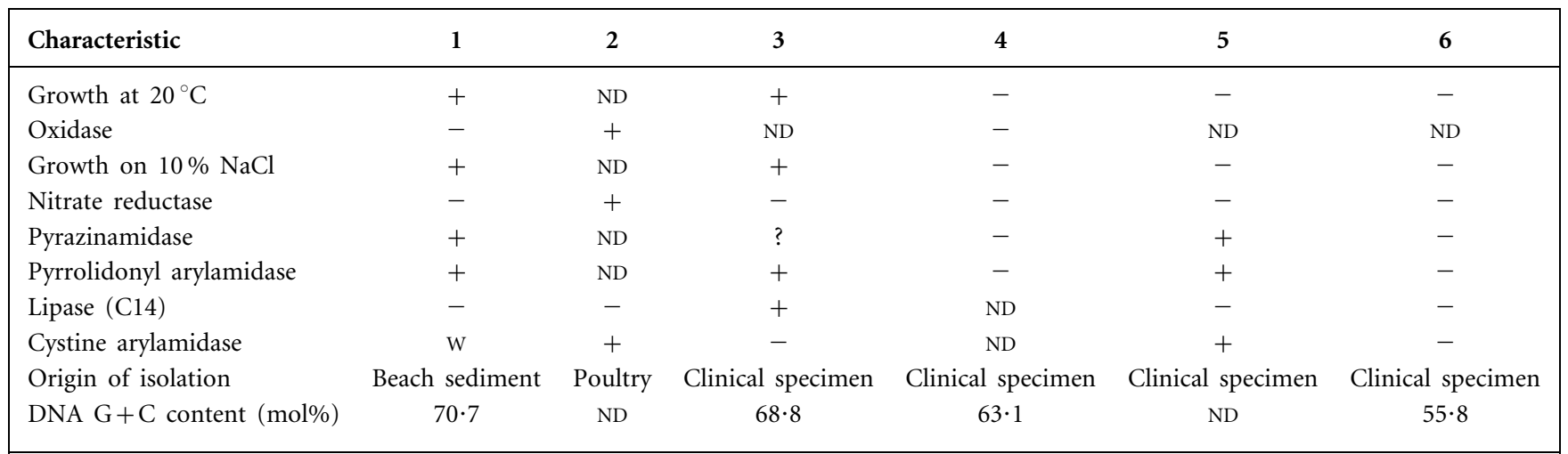


hydrolysis and fermentation of D-ribose, D-xylose, Dmannitol, D-lactose and glycogen are negative. Acid production from D-glucose, D-maltose and sucrose are weakly positive. In additional tests with the API ZYM system, esterase (C4), esterase lipase (C8), leucine arylamidase, trypsin and naphthol-AS-BI-phosphohydrolase are positive. Valine arylamidase and cystine arylamidase are weakly positive. The following give negative responses: lipase (C14), $\alpha$-chymotrypsin, acid phosphatase, $\alpha$-galactosidase, $\beta$-glucuronidase, $\beta$-glucosidase, $N$-acetyl- $\beta$-glucosaminidase, $\alpha$ mannosidase and $\alpha$-fucosidase. The phospholipid profiles contain diphosphatidylglycerol. Mycolic acids are not present. The major cellular fatty acids are anteiso- $\mathrm{C}_{17: 0}$, anteiso- $\mathrm{C}_{15: 0}$ and iso- $\mathrm{C}_{15: 0}$. The $\mathrm{G}+\mathrm{C}$ content of the DNA is $70 \cdot 7 \mathrm{~mol} \%$.

The type strain, SST $-8^{\mathrm{T}} \quad\left(=\mathrm{NRRL} \quad \mathrm{B}-41420^{\mathrm{T}}=\mathrm{KCCM}\right.$ $42316^{\mathrm{T}}$ ), was isolated from sand sediment of Samyang Beach, Jeju Island, Republic of Korea.

\section{Acknowledgements}

This work was supported by the 21C Frontier Microbial Genomics and Application Center Program, Ministry of Science \& Technology, Republic of Korea. I am grateful to H. L. Yang for fatty acid analysis and D. W. Lee for the determination of DNA G + C content.

\section{References}

Breed, R. S. (1953). The families developed from Bacteriaceae Cohn with a description of the family Brevibacteriaceae. Riass Commun VI Congr Int Microbiol Roma 1, 10-15.

Collins, M. D., Farrow, J. A. E., Goodfellow, M. \& Minnikin, D. E. (1983). Brevibacterium casei sp. nov. and Brevibacterium epidermidis sp. nov. Syst Appl Microbiol 4, 388-395.

Felsenstein, J. (1981). Evolutionary trees from DNA sequences: a maximum likelihood approach. J Mol Evol 17, 368-376.

Felsenstein, J. (1985). Confidence limits on phylogenies: an approach using the bootstrap. Evolution 39, 783-791.

Fitch, W. M. (1971). Towards defining the course of evolution: minimum change for a specific tree topology. Syst Zool 20, 406-416.

Funke, G. \& Carlotti, A. (1994). Differentiation of Brevibacterium spp. encountered in clinical specimens. J Clin Microbiol 32, 1729 1732.

Gordon, R. E., Barnett, D. A., Handerhan, J. E. \& Pang, C. H.-N. (1974). Nocardia coeliaca, Nocardia autotrophica, and the nocardin strain. Int J Syst Bacteriol 24, 54-63.

Heyrman, J., Verbeeren, J., Schumann, P., Devos, J., Swings, J. \& Vos, P. D. (2004). Brevibacterium picturae sp. nov., isolated from a damaged mural painting at the Saint-Catherine chapel (Castle Herberstein, Austria). Int J Syst Evol Microbiol 54, 1537-1541.

Ivanova, E. P., Christen, R., Alexeeva, Y. V., Zhukova, N. V., Gorshkova, N. M., Lysenko, A. M., Mikhailov, V. V. \& Nicolau, D. V. (2004). Brevibacterium celere sp. nov., isolated from degraded thallus of a brown alga. Int J Syst Evol Microbiol 54, 2107-2111.

Jones, D. \& Keddie, R. M. (1986). Genus Brevibacterium. In Bergey's Manual of Systematic Bacteriology, vol. 2, pp. 1301-1313. Edited by
P. H. A. Sneath, N. Mair, M. E. Sharpe \& J. G. Holt. Baltimore: Williams \& Wilkins.

Jukes, T. H. \& Cantor, C. R. (1969). Evolution of protein molecules. In Mammalian Protein Metabolism, pp. 21-132. Edited by H. N. Munro. New York: Academic Press.

Kroppenstedt, R. M. (1985). Fatty acid and menaquinone analysis of actinomycetes and related organisms. In Chemical Methods in Bacterial Systematics, pp. 173-199. Edited by M. Goodfellow \& D. E. Minnikin. London: Academic Press.

Lee, S. D., Kang, S.-O. \& Hah, Y. C. (2000a). Hongia gen. nov., a new genus of the order Actinomycetales. Int J Syst Evol Microbiol 50, 191199.

Lee, S. D., Kim, E. S., Roe, J.-H., Kim, J.-H., Kang, S.-O. \& Hah, Y. C. (2000b). Saccharothrix violacea sp. nov., isolated from a gold mine cave, and Saccharothrix albidocapillata comb. nov. Int J Syst Evol Microbiol 50, 1315-1323.

McBride, M. E., Ellner, K. M., Black, H. S., Clarridge, J. E. \& Wolf, J. E. (1993). A new Brevibacterium sp. isolated from infected genital hair of patients with white piedra. J Med Microbiol 39, 255-261.

Minnikin, D. E., Alshamaony, L. \& Goodfellow, M. (1977). Differentiation of Mycobacterium, Nocardia, and related taxa by thin layer chromatographic analysis of whole-cell methanolysates. J Gen Microbiol 88, 200-204.

Minnikin, D. E., Hutchinson, I. G., Caldicott, A. B. \& Goodfellow, M. (1980). Thin layer chromatography of methanolysates of mycolic acid-containing bacteria. J Chromatogr 188, 221-233.

Pascual, C. \& Collins, M. D. (1999). Brevibacterium avium sp. nov., isolated from poultry. Int J Syst Bacteriol 49, 1527-1530.

Pascual, C., Collins, M. D., Funke, G. \& Pitcher, D. G. (1996). Phenotypic and genotypic characterization of two Brevibacterium strains from the human ear: description of Brevibacterium otitidis sp. nov. Med Microbiol Lett 5, 113-123.

Saitou, N. \& Nei, M. (1987). The neighbor-joining method: a new method for reconstructing phylogenetic trees. Mol Biol Evol 4, 406425.

Shirling, E. B. \& Gottlieb, D. (1966). Methods for characterization of Streptomyces species. Int J Syst Bacteriol 16, 313-340.

Stackebrandt, E. \& Goebel, B. M. (1994). Taxonomic note: a place for DNA-DNA reassociation and 16S rRNA sequence analysis in the present species definition in bacteriology. Int J Syst Bacteriol 44, 846849.

Staneck, J. L. \& Roberts, G. D. (1974). Simplified approach to identification of aerobic actinomycetes by thin-layer chromatography. Appl Microbiol 28, 226-231.

Thompson, J. D., Gibson, T. J., Plewniak, F., Jeanmougin, F. \& Higgins, D. G. (1997). The CLUSTAL_X windows interface: flexible strategies for multiple sequence alignment aided by quality analysis tools. Nucleic Acids Res 25, 4876-4882.

Wauters, G., Charlier, J., Janssens, M. \& Delmée, M. (2001). Brevibacterium paucivorans sp. nov., from human clinical specimens. Int J Syst Evol Microbiol 51, 1703-1707.

Wauters, G., Avesani, V., Laffineur, K., Charlier, J., Janssens, M., Van Bosterhaut, B. \& Delmée, M. (2003). Brevibacterium lutescens sp. nov., from human and environmental samples. Int $J$ Syst Evol Microbiol 53, 1321-1325.

Wauters, G., Haase, G., Avesani, V., Charlier, J., Janssens, M., Broeck, J. V. \& Delmée, M. (2004). Identification of a novel Brevibacterium species isolated from humans and description of Brevibacterium sanguinis sp. nov. J Clin Microbiol 42, 2829-2832. 